\title{
Milking Temperament Influence on Production Performance and Plasma Hormones in Sahiwal Cows
}

\author{
P. Tamboli ${ }^{1 *}$, R. Chandra ${ }^{1}$, M. Singh ${ }^{1}$, A. Chaurasiya ${ }^{2}$ and B. Sharma ${ }^{3}$ \\ ${ }^{1}$ ICAR-NDRI, Karnal-132001, Haryana, India \\ ${ }^{2}$ ICAR-IVRI, Bareilly-243122, UP, India \\ ${ }^{3}$ LUVAS, Hisar-125001, Haryana, India \\ *Corresponding author
}

\begin{abstract}
A B S T R A C T
Present study was conducted to explore the effect of milking temperament on milking attributes like milk let down time, milking time, milk flow rate, milk yield, composition in relation to plasma cortisol level and reproductive performance in Sahiwal cows. The experiment was carried out on 88 lactating healthy Sahiwal cows in hot- humid (38) and winter (58) season. The milking temperament was scored and the cows were grouped as

docile and restless. Milking attributes like milk let down time, milking time and milking rate was determined in each season. Plasma cortisol was estimated and the reproductive performance of all the animals was recorded. Milking temperament did not influence milk let down time, milking time, total milking time, milk flow rate and milk yield in both the seasons of experiment however, fat $(\mathrm{P}<0.01)$ and total solids $(\mathrm{P}<0.05)$ were higher in restless animals as compared to docile in hot-humid season. Mean body condition score (BCS) was non-significant between the group $(\mathrm{p}>0.05)$ in both the seasons. Mean milk SCC was lower $(\mathrm{P}<0.01)$ in docile as compared to restless animals in hot-humid season, but did not vary in winter season. Plasma cortisol level was significantly lower $(\mathrm{P}<0.01)$ and IGF-I, IgG was lower $(\mathrm{P}<0.01)$ in docile animals than the restless in both the seasons. Docile cows exhibited first post-partum heat earlier $(\mathrm{P}<0.05)$ and had less service period $(\mathrm{P}<0.01)$ than the restless. It was concluded that temperament at milking influences milk fat \%, total solids and SCC of milk. Restless temperament of Sahiwal cows at milking lead to elevated plasma cotisol and lower IGF-I hormone level in Sahiwal cows which are associated with milk production.
\end{abstract}

\section{Keywords}

Temperament, Sahiwal, Docile, Restless, Milking

Article Info

Accepted:

10 June 2018

Available Online:

10 July 2018

\section{Introduction}

The temperament of animals is generally considered innate and it is determined by animal's physical and nervous organization, and is affected by external factors also (Prasad and Laxmi, 2014). Proper handling and management are important for temperament and higher milk yield (Rasmussen and Reinemann, 2010). Good temperament is often equated with or used to describe calm behavior of the animal while poor temperament describes an animal that appears more disturbed and agitated (Herve et al., 2007). It has been found that nervous type animals require longer let-down time in 
Murrah buffaloes and Karan Fries cows, respectively (Roy and Nagpaul, 1984). Aggressive buffaloes take maximum time in total milking and in let down time mainly due to difficulty in handling at milking (Gupta $e t$ al., 1985). Aggressive cows also require more time because worker spent maximum time for milking due to more let down time and difficulty in handling of animals at milking (Chauhan et al., 2013). Contrary to this cows with docile temperament took minimum letdown time. A number of studies in exotic cows and buffaloes reveal crucial role of temperament at milking in getting the good yield and quality milk. At the same time it adversely affects milk let down time and in turns milking management of animals. Though considerable information is available in exotic cows and buffaloes however in Indigenous heat tolerant Sahiwal cows the information is very scanty (Pathak, 2002). Also very few studies have been focused on the association between production traits and milking temperament. Keeping in view, the present study was designed to find out the effect of milking temperament on different milking attributes and reproductive performance in association with hormones and immunoglobulin levels in lactating Sahiwal cows.

\section{Materials and Methods}

The experiment was conducted on 38 lactating healthy Sahiwal cows in hot humid and 50 cows during winter season. The cows were grouped as docile and restless on the basis of milking temperament at the time of milking. These were managed in loose housing system and were fed as per the feeding management practices of institute herd. The Sahiwal cows were machine milked thrice a day at 5am, 12 noon and $6 \mathrm{pm}$ and the yields were recorded. The experiment was carried out during the summer (Hot-humid) and winter (Dec. - Jan.) seasons. During hot-humid season humidity was more than $85 \%$ and temperature ranged from $36^{\circ} \mathrm{C}-37^{\circ} \mathrm{C}$ than the winter season temperature of $13^{\circ} \mathrm{C}-15^{\circ} \mathrm{C}$ (min.) and $20-24^{\circ} \mathrm{C}$ (max.). Milk samples were collected at each milking and aliquots of milk samples from individual animal were composited in proportion to their milk yield. Milk fat, protein, lactose, SNF and total solids were measured using Milkoscan. The observations on let down time, milking time, total milking time was recorded by a digital stop watch. Milking temperament was recorded for two consecutive days at each milking. Body condition score was also recorded as described by Balakrishnan et al., (1997) in each season. Milk SCC was determined by somatic cell analyzer (Ekomilk scan). Plasma cortisol, IGF-1 and total immunoglobulin (IgG) levels were estimated by Enzyme-linked Immunosorbent Assay Kit (Bioassay Technology Laboratory). The statistical analysis of the data was carried out by 2-way least square analysis (SPSS 20.0 computer software) and the mean and standard errors were calculated. The significance of the differences between the means of various parameters was tested for significance. The plan of experiment was duly approved by the Institutional Animal Ethical Committee.

\section{Results and Discussion}

The percent incidences of docile and restless Sahiwal cows were higher in summer 68.95 vs. $31.05 \%$ ) than the winter season (60.57 vs. $39.43 \%$ ). The behaviour of Sahiwal cows did not influenced milking attributes like milk let down time, milking time and total milking time significantly though values were numerically lower in docile as compared to restless cows (Table 1). The lower milking time and total milking time observed in docile cows was due to docile and easy milking behavior of cows and is in agreement with the report of Roy and Nagpaul (1984). Further aggressive animals required the maximum 
time in total milking due to more let down time and difficulty in handling of animals at the time of milking (Gupta et al., 1985). This was the reason that milk flow rate and milk yields were higher in docile as compared to restless cows in both the seasons. Milk flow rate was non-significantly higher in docile as compared to restless Sahiwal cows. Studies in buffaloes also reveal that docile buffaloes produce more milk $(\mathrm{P}<0.05) /$ milking with highest average milk flow rate in the shortest possible time (Gupta et al., 1985). However buffaloes having a temperament score of five (more temperament) were poor yielders and those with a score of one and two (good temperament) were good milk yielders and had higher daily milk yield (Prasad et al., 2011). Several reports also indicated similar observations on higher milk yield in docile animals than the aggressive (Prasad and Laxmi, 2014). The observed high milk flow rate in docile cows than the restless ones was attributed to maximum time in milking operation in order of aggressive followed by nervous, restless and minimum time recorded in docile cows (Chauhan et al., 2013). The minimum let-down time in cows with docile temperament further indicate that cows comfortable behaviour at milking possess full milking potential while Sahiwal cows with aggressive temperament took more letdown time indicating that restless nature is not good for a milking animal. Milk fat $\%$ ranged between 2.8 to 6.2 in docile vs. 3.2 to 6.8 in restless cows during summer and 2.13 to 6.2 $\%$ in docile vs. 2.3 to $5.8 \%$ in restless during winter season. Total solids was non-significant in docile and restless cows and ranged between 12.46 to 15.4 vs. 10.52 to 16.27 in summer and 10.86 to 15.52 vs. 11.86 to 15.52 in winter seasons, respectively (Table 2). Protein and lactose content of milk was not influenced by temperament. Milk fat $(\mathrm{P}<0.01)$ and TS $(\mathrm{P}<0.05)$ percentage was more in restless as compared to docile cows in hothumid season. Protein (\%) was higher $(\mathrm{P}<0.05)$ in restless animals as compared to docile in winter season (Table 2). The BCS of docile and restless cows did not vary and ranged between 2.4 to 3.9 vs. 3.0 to 4.0 in hothumid and from 3.0 to 4.0 vs. 3.0 to 4.0 during winter season, respectively (Table 3 ). Milk SCC was more in restless than the docile cows and was 88 to 312 vs. 110 to $332 \times 10^{3}$ cells $/ \mathrm{ml}$ in hot-humid and 67 to 287 vs. 67 to $288 \times 10^{3}$ cells/ml in winter (Table 3).

Table.1 Effect of temperament on different milking parameters in Sahiwal cows milked thrice a day in two different seasons

\begin{tabular}{|l|l|l|}
\hline $\begin{array}{l}\text { Temperament score } \\
\text { Milk let-down time (seconds) }\end{array}$ & Hot-humid season & Winter season \\
\hline $\begin{array}{l}\text { Docile } \\
\text { Restless }\end{array}$ & $18.87 \pm 0.94^{\mathrm{a}}$ & $33.68 \pm 1.88^{\mathrm{a}}$ \\
\hline Milking time (Min.) & $19.95 \pm 3.82^{\mathrm{a}}$ & $39.71 \pm 2.86^{\mathrm{b}}$ \\
\hline Docile & $6.18 \pm 0.14$ & $5.17 \pm 0.20$ \\
\hline Restless & $6.53 \pm 0.61$ & $5.23 \pm 0.25$ \\
\hline Total milking time (Min.) & & \\
\hline Docile & $6.47 \pm 0.15$ & $5.520 \pm 0.20$ \\
\hline Restless & $7.18 \pm 0.63$ & $6.176 \pm 0.26$ \\
\hline Milk flow rate (kg/min.) & & \\
\hline Docile & $0.46 \pm 0.02$ & $0.61 \pm 0.03$ \\
\hline Restless & $0.41 \pm 0.06$ & $0.55 \pm 0.03$ \\
\hline
\end{tabular}


Table:2 Effect of temperament on milk yield and milk composition of Sahiwal cows milked thrice a day in two different seasons

\begin{tabular}{|c|c|c|}
\hline Temperament score & Hot-humid season & Winter season \\
\hline \multicolumn{3}{|c|}{ Milk yield (kg) } \\
\hline Docile & $8.43 \pm 0.59^{a}$ & $10.68 \pm 0.72^{\mathrm{a}}$ \\
\hline Restless & $7.54 \pm 0.93^{\mathrm{a}}$ & $9.18 \pm 0.61^{\mathrm{a}}$ \\
\hline \multicolumn{3}{|c|}{ Milk Composition } \\
\hline \multicolumn{3}{|c|}{ Fat $(\%)$} \\
\hline Docile & $4.44^{\mathrm{A}} \pm 0.04$ & $4.19 \pm 0.08$ \\
\hline Restless & $4.84^{\mathrm{B}} \pm 0.19$ & $4.03 \pm 0.07$ \\
\hline \multicolumn{3}{|c|}{ SNF (\%) } \\
\hline Docile & $9.44 \pm 0.03$ & $9.77 \pm 0.05$ \\
\hline Restless & $9.44 \pm 0.09$ & $9.83 \pm 0.05$ \\
\hline \multicolumn{3}{|c|}{ TS $(\%)$} \\
\hline Docile & $13.87^{\mathrm{A}} \pm 0.04$ & $13.98 \pm 0.08$ \\
\hline Restless & $14.19^{\mathrm{B}} \pm 0.25$ & $13.86 \pm 0.09$ \\
\hline \multicolumn{3}{|c|}{ Protein (\%) } \\
\hline Docile & $3.16 \pm 0.02$ & $3.05^{\mathrm{A}} \pm 0.03$ \\
\hline Restless & $3.12 \pm 0.04$ & $3.12^{\mathrm{B}} \pm 0.02$ \\
\hline \multicolumn{3}{|c|}{ Lactose (\%) } \\
\hline Docile & $4.74 \pm 0.20$ & $4.71 \pm 0.03$ \\
\hline Restless & $4.53 \pm 0.05$ & $4.72 \pm 0.03$ \\
\hline
\end{tabular}

Values with different superscripts A, B differs $(\mathrm{P}<0.05)$ in a column significantly

Table.3 Effect of temperament on somatic cell count and body condition score in Sahiwal cows milked thrice a day in two different seasons

\begin{tabular}{|c|c|c|}
\hline Temperament score & \multicolumn{1}{|c|}{ Hot-humid season } & Winter season \\
\hline & Somatic cell counts $\left(\times \mathbf{1 0}^{\mathbf{3}}\right)$ & \\
\hline Docile & $159.98^{\mathrm{A}} \pm 3.06^{\mathrm{a}}$ & $144.25 \pm 5.07^{\mathrm{a}}$ \\
\hline Restless & $192.54^{\mathrm{B}} \pm 12.78^{\mathrm{b}}$ & $145.16 \pm 4.88^{\mathrm{a}}$ \\
\hline & Body condition score & \\
\hline Docile & $3.57 \pm 0.03^{\mathrm{a}}$ & $3.72 \pm 0.03^{\mathrm{a}}$ \\
\hline Restless & $3.48 \pm 0.04^{\mathrm{a}}$ & $3.68 \pm 0.03^{\mathrm{a}}$ \\
\hline
\end{tabular}

Values with different superscripts $a, b$ differs $(\mathrm{P}<0.05)$ in a column

Table.4 Effect of temperament on reproductive performance in Sahiwal cows milked thrice a day in two different seasons

\begin{tabular}{|c|c|c|}
\hline Temperament score & Hot-humid season & Winter season \\
\hline & First observed post-partum heat (days) & \\
\hline Docile & $70.70^{\mathrm{a}} \pm 4.74$ & $64.31^{\mathrm{a}} \pm 3.01$ \\
\hline Restless & $85.61^{\mathrm{b}} \pm 4.57$ & $79.07^{\mathrm{b}} \pm 3.43$ \\
\hline & \multicolumn{2}{|c|}{ Service period (days) } \\
\hline Docile & $101.25^{\mathrm{a}} \pm 4.04$ & $94.56^{\mathrm{a}} \pm 3.30$ \\
\hline Restless & $141.72^{\mathrm{b}} \pm 4.67$ & $121.53^{\mathrm{b}} \pm 3.84$ \\
\hline & No. of Service per conception & \\
\hline Docile & $1.45^{\mathrm{a}} \pm 0.135$ & $1.31 \pm 0.12^{\mathrm{a}}$ \\
\hline Restless & $1.89^{\mathrm{b}} \pm 0.16$ & $1.67 \pm 0.16^{\mathrm{b}}$ \\
\hline
\end{tabular}

Values with different superscripts a, b differs $(\mathrm{P}<0.05)$ in a column 
Fig.1 Effect of milking temperament on plasma hormones during different season in lactating Sahiwal cows

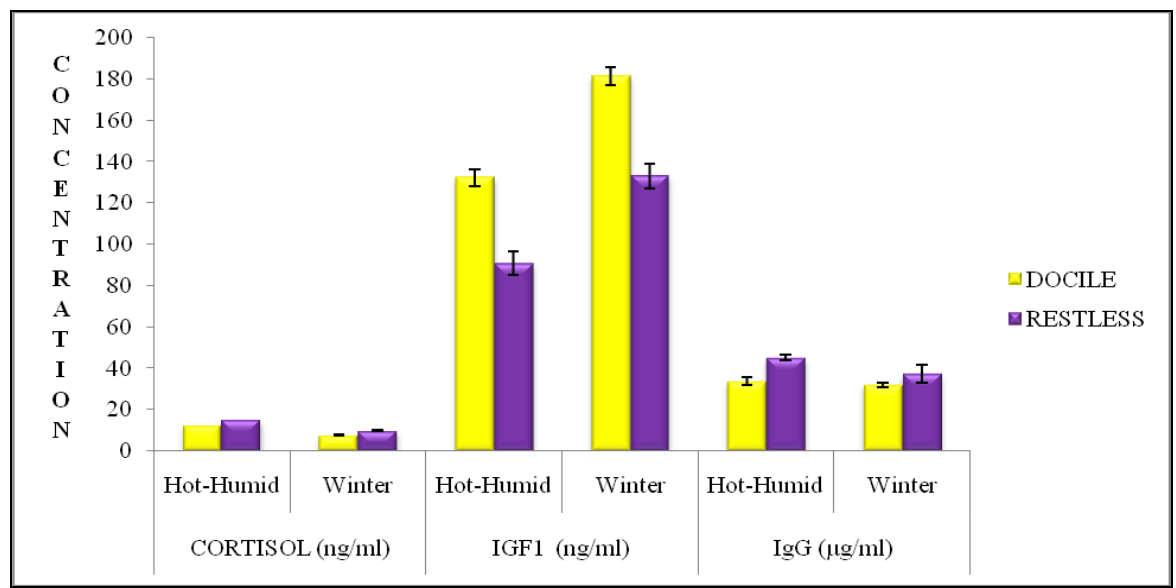

The significantly lower $(P=0.01)$ SCC in calmer cows as compared to temperamental ones has been reported by Orban et al., (2011). Thus calmer cows with low SCC produced more hygienic milk then temperamental animals (Gergovska et al., 2014). Plasma cortisol level was less in docile $(12.37 \pm 0.20 \mathrm{ng} / \mathrm{ml})$ than the restless cows $(15.03 \pm 0.19 \mathrm{ng} / \mathrm{ml})$ in hot-humid and winter season $(7.67 \pm 0.08$ vs. $9.77 \pm 0.14$ ng/ml; Fig. 1).

The significantly lower cortisol level in winter season was due to the low ambient temperature as high temperature increase plasma cortiosl levels (Pajor et al., 2010; Curley et al., 2006 and King et al., 2006). The temperamental cattle display an endophenotype of chronic stress due to which cortisol concentrations are elevated as in depression (Curley et al., 2008, 2010). Plasma IGF-1 level was higher in docile (132.38 $4.17 \mathrm{ng} / \mathrm{ml})$ than the restless cows $(90.76 \pm 5.68$ $\mathrm{ng} / \mathrm{ml}$ ) in hot-humid season and winter season $(181.52 \pm 4.17$ vs. $133.17 \pm 6.00 \mathrm{ng} / \mathrm{ml})$ and suggested a galactopoietics effect on milk yield. The higher IGF-I level could be attributed to better production and reproduction performance in docile animals. IGF-1 is also recognized as a signal that controls reproductive function, the IGF-1 system and its interaction with the reproductive axis may account for increased reproductive efficiency. Cows with better reproductive performance have been found to have higher concentrations of circulating IGF1 (Meikle et al., 2004).

The IgG levels were lower in docile than the restless cows $(33.84 \pm 1.83$ vs. $45.12 \pm 1.30$ $\mu \mathrm{g} / \mathrm{ml})$ in hot-humid and winter season (31.88 \pm 0.91 vs. $37.45 \pm 4.21 \mu \mathrm{g} / \mathrm{ml}$ ) (Fig. 1). The higher $\operatorname{IgG}$ level $(\mathrm{P}<0.01)$ in restless animals could probably due to restless behavior and indicated more susceptible to infections. Though temperamental steers have lower in-vitro lymphocyte proliferation and lower in-vivo IgG concentrations as compared to calm steers (Oliphint, 2006).

The onset of first observed post-partum heat was earlier in docile (24 to 107days) than the restless cows (56 to 136 days) in hot-humid and in winter season (45 to $87 \mathrm{Vs} .58$ to 106 days). The service period was higher in restless (117 to 200days) than the docile cows (60 to 129days) during hot-humid and winter season (75 to 115 vs. 96 to 144 days). Average number of services/conception was less in docile than the restless animals (Table 4 ) in hot humid (1 to 3 vs. 1 to 3 ) and winter season ( 1 to 2 vs. 1 to 3 ). The better 
reproductive performance of docile cows in both the seasons was indicative of adverse effects of excitable behavior of cows leading to poor reproductive performance than docile (calmer) cows by influencing hormone of reproduction (Kasimanickam et al., 2014 and Rueda et al., 2015).

In conclusion, indigenous Sahiwal cows having docile behavior at milking exhibit higher milk production performance than the aggressive Sahiwal cows. Restless temperament at milking results in more time in milking operations. Such cows have higher milk SCC and plasma cortisol and lower $\mathrm{IGF}_{1}$ levels resulting in poor reproductive performance than the docile cows.

\section{References}

Balakrishnan, M., Ramesha, K. P. and Chinnaiya, G. P. 1997. Effect of post partum body condition loss on performance in crossbred cows, an assessment through body condition score. Indian Journal of Dairy Science 50(5): 393-397.

Chauhan, H. D., Patel, H. A. and Ankuya, K. J. 2013. Effect of dairy temperament on milkability of lactating Kankrej cows. Wayamba Journal of Animal Science 578: 554-557.

Curley Jr, K. O., Neuendorff, D. A., Lewis, A. W., Cleere, J. J., Welsh, T. H. and Randel, R. D. 2008. Functional characteristics of the bovine hypothalamic-pituitary-adrenal axis vary with temperament. Hormones and Behavior 53: 20-27.

Curley Jr, K. O., Neuendorff, D. A., Lewis, A. W., Rouquette, F. M., Randel, R. D. and Welsh, T. H. 2010. The effectiveness of vasopressin as an ACTH secretagogue in cattle differs with temperament. Physiological Behaviour 101: 699-704.
Curley Jr, K. O., Paschal, J. C., Welsh, T. H. and Randel, R. D. 2006. Technical note: exit velocity as a measure of cattle temperament is repeatable and associated with serum concentration of cortisol in Brahman bulls. Journal of Animal Science 84: 3100-3103.

Gergovska, Z. H., Marinov, I., Penev, T. and Angelova, T. 2014. Effect of milking temperament on productive traits and SCC in Black-and-White cows. International Journal of Current Microbiology and Applied Sciences 3 (8): 1-11.

Gupta, S. C., Handa, M. C. and Sahoo, G. 1985. Dairy temperament of buffaloes in relation to their milking ability. Indian Journal of Animal Production and Management 1(3): 116-119.

Herve, J., Szentleleki, A. and Tozser, J. 2007. Catlle's behaviour perceptions, relationships, studies and measurements of temperament. Animal welfare, ethology and housing systems 3: 27-47.

Kasimanickam, R., Schroeder, S., Assay, M., Kasimanickam, V., Moore, D. A., Gay, J. M. and Whittier, W. D. 2014. Influence of temperament score and handling facility on stress, reproductive hormone concentrations, and fixed time AI pregnancy rates in beef heifers. Reproduction in Domestic Animals 49:775-782.

King, D. A., Schuehle Pfeiffer, C. E. and Randel, R. D. 2006. Influence of animal temperament and stress responsiveness on the carcass quality and beef tenderness of feedlot cattle. Meat Science 74: 546-556.

Meikle, A., Kulscar, M., Chilliard, Y., Febel, H., Delavaud, C., Cavestany, D. and Chilibroste, P. 2004. Effects of parity and body condition at parturition on endocrine and reproductive parameters of the cow. Reproduction 127: 727- 
737.

Oliphint, R. A. 2006. Evaluation of the interrelationships of temperament, stress responsiveness and immune function in beef calves. M.S. thesis. Texas A\&M University, College Station, USA.

Orban, M., Gaal, K. K., Pajor, F., Szentleleki, A., Poti, P., Tozser, J. and Gulyas, L. 2011. Effect of temperament of Jersey and Holstein Friesian cows on milk production traits and somatic cell count (Short Communication). Archiv fur tierzucht-archives of animal breeding 54 (6): 594-599.

Pajor, F., Muranyi, A., Szentleleki, A., Tozser, J. and Poti, P. 2010. Effect of temperament of ewes on their maternal ability and their lambs' postweaning traits in Tsigai breed. Archiv fur tierzucht-archives of animal breeding 53: 465-474.

Pathak, P. K. 2002. Comparative studies on milking temperament and somatic cell count of sahiwal cows and Murrah buffaloes under hand and machine milking systems. M.Sc. Thesis, Deemed University, NDRI, Karnal,
India.

Prasad, R. M. V. and Jaya Laxmi, P. 2014. Studies on the temperament of murrah buffaloes with various udder and teat shapes and its effect on milk yield. Buffalo Bulletin 33: 170-176.

Prasad, R. M. V., Jaya Laxmi, P. and Sreenivas Kumar, D. 2011. Temperament of Murrah buffaloes in different lactations and its effect on the milk yield. Indian Journal of Animal Research 45: 219 - 222.

Rasmussen, M. D. and Reinemann, D. J. 2010. Milking management. In IDF Mastitis Conference, Christchurch, NewZealand.

Roy, P. K. and Nagpaul, P. K. 1984. Studies on effect of temperament score on different traits in dairy animals. Indian Journal of Animal Science 37: 74-75.

Rueda, P. M., Anna, A. C. S., Valente, T. S., Mateus, J. R. and Costa, P. D. 2015. Impact of the temperament of Nellore cows on the quality of handling and pregnancy rates in fixed-time artificial insemination. Livestock Science 177: 189-195.

\section{How to cite this article:}

Tamboli, P., R. Chandra, M. Singh, A. Chaurasiya and Sharma, B. 2018. Milking Temperament Influence on Production Performance and Plasma Hormones in Sahiwal Cows. Int.J.Curr.Microbiol.App.Sci. 7(07): 1283-1289. doi: https://doi.org/10.20546/ijcmas.2018.707.153 